\section{India's too costly imports}

SIR-I write in support of the views of Patrick J. Willems in his note on 'Primer availability' for his prenatal diagnosis work (Nature 337, 10;1989) and I would like to add to them. I am sure that my counterparts in this country and in other countries in this part of the world face similar problems in pursuing their research in molecular biology.

Some United States-based companies charge us very high prices for molecular biology reagents - far more than the true catalogue prices. I calculate that if I were working in a US laboratory, I would receive enzymes and reagents at half the price I have to pay in India. Whenever we ask for quotation, the prices quoted are one and a half times greater than catalogue prices. But the extra handling charges are exorbitant, sometimes half of the total cost. We also pay insurance charges, customs charges, freight charges and local agents' commission.

Laboratory instrumentation is another problem. One US company quoted $\$ 120,000$ to us for an automatic nucleotide sequencer sold in the United States for $\$ 90,000$. When I sought an explanation from one of the company's managers (who was visiting India to demonstrate the instrument) the answer was highly unsatisfactory.

These companies even give a discount in the United States on their catalogue prices. Here, we are willing to pay all their extra charges yet we are forced to pay over and above the catalogue prices. What for? We already suffer from procedural delays when trying to obtain equipment from abroad, so an item which one can procure in a US laboratory on the same day, or the next morning, takes several months to reach an Indian customer. Yet we maintain our good work, which is quite competitive, even though, sadly, some foreign journals show bias in accepting our results. So a scientist in this part of the world suffers from both sides.

Will the companies not change their attitude and look into the matter more seriously for the betterment of science, which is serving humanity all over the world?

Department of Biotechnology,

Y. D. SARMA All India Institute of Medical Sciences, New Delhi - 110 029, India

\section{Food comes first}

SIR-In return for the 'India in France' festival, France is constructing in New Delhi an Indo-French Centre for Advanced Research as part of the 'France in India' festival. It is hoped that this institution will be an effective centre for excellence in scientific research and will not fall prey to the maladies gripping other such establishments in India, where science and research are in jeopardy.

India has a network of research laboratories, some well-equipped even by European standards. But for reasons debated earlier in these columns, most research centres in India, in spite of the availability of capable men and sufficient materials, have lagged behind in contributing their share to scientific growth.

Indian scientific circles are aware of this fact but no effort has been made to root out retrogressive forces impeding adequate scientific progress in India, where sycophancy rules supreme. Several commissions have been instituted to recommend remedial measures, but the fate of these recommendations is usually to end up gathering dust on government shelves.

The Centre for Advanced Research which France is building must be made to run as a first-class research centre under French guidance before being handed over. Otherwise there is a danger that the proposed centre will join dozens of other research centres where excellence in science is sacrificed to vested interests.

In France there exists an efficient means of producing milk and cheese at village or departmental level. If this system could be demonstrated in India during the 'French Festivities' as a model, it would be of practical value for the nutrition of the Indian masses, 80 per cent of whom live on a vegetarian diet. Agricultural production and nutrition deserve priority in IndoFrench ventures.

\section{CNRS,}

A. N. MalviYa

5, rue Blaise Pascal,

67084 Strasbourg Cedex,

France

\section{Cry from the past}

SIR-While sorting through the papers of the late Martin D. Burkenroad held in the archives of the San Diego Society of Natural History, the following letter was found.

January 10th, 1939

Prof. Williard G. Van Name

American Museum of Natural History

New York City, USA

Dear Sir,

I hope that you will forgive me for taking the liberty of writing to you in this way. I have been working as an assistant at the Istituto di Anatomia Comparata della R. Universita di Napoli for five years.

Last month, owing to the laws against the Jews, I lost my position and since there are no further prospects here for me, I would be really much obliged to you if you would let me know whether there are any possibilities of obtaining employment in the United States of America.

I am a Doctor of Natural Science, twenty five years of age, with a fair knowledge of English,
French, Russian and, of course, Italian. I have had a thorough training in Zoology and Comparative Anatomy and I have published twelve scientific papers up to the present. I have devoted myself to biological research, and have also had considerable experience in training and organizing.

If there is any possibility in the United States of getting a technical position in Biology, I am quite ready to work as a secretary: in fact, I have also had much experience in bookkeeping, typing, and general office routine.

I most sincerely hope that you will excuse me for all the trouble to which I am putting you.

Thanking you in anticipation.

I am

Yours very faithfully

(Signed) Isabella Coifmann

Apparently, Prof. W.G. Van Name had forwarded the letter to Burkenroad in the hope that there might have been an open position at Yale's Bingham Oceanographic Laboratory. That the department volunteer who was assisting me with the sorting of Burkenroad's papers, and who brought this item to my attention, is himself Jewish, added to the letter's poignancy. Besides sharing this footnote in history with the readers of Nature, we at the San Diego Natural History Museum would like to know whatever happened to $\mathrm{Dr}$ Coifmann. If someone has any information in this matter, please contact us.

Department of Paleontology,

FREDERICK R. SCHRAM

San Diego Natural History Museum,

PO Box 1390,

San Diego, California 92112, USA

\section{Mistaken identity?}

SIR-The photograph issued by NASA purporting to be a photomosaic of Phobos (Nature 339, 9; 1989) bears a quite remark-

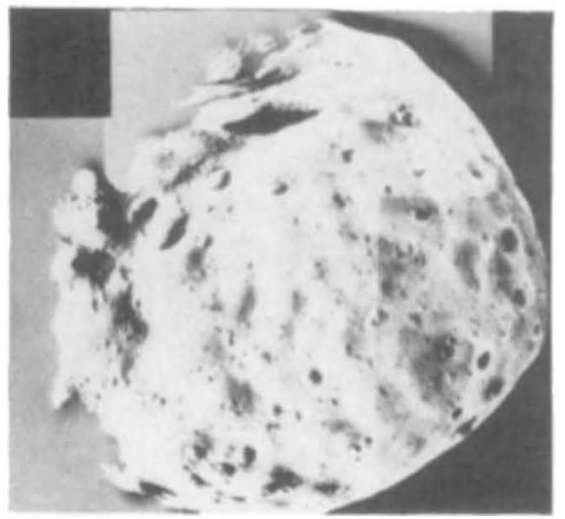

Assuredly a martian moon

able resemblance to a fried spicy poppadam (samples of which are available in all good Indian take-aways). Is fraud to be suspected?

Department of Zoology,

LAURENCE D. HURST

University of Oxford,

South Parks Road,

Oxford OX1 3PS, UK 